\title{
The New Normal in Indonesia: A Twitter Based Social Media Analysis
}

\author{
Dhite Bayu Nugroho 1,2, ${ }^{*}$, Mawaddah Ar Rochmah', Faridatun Khasanah², Fajar Fatmawati , Al Razi Sena² \\ ${ }^{1}$ Department of Internal Medicine, Faculty of Medicine, Public Health, and Nursing, Universitas Gadjah Mada, Yogyakarta, \\ Indonesia, 55281 \\ ${ }^{2}$ Clinical Epidemiology and Biostatistics Unit, Faculty of Medicine, Public Health, and Nursing, Universitas Gadjah Mada, \\ Yogyakarta, Indonesia, 55281 \\ ${ }^{3}$ Department of Neurology, Faculty of Medicine, Public Health, and Nursing, Universitas Gadjah Mada, Yogyakarta, Indonesia, \\ 55281
}

\begin{abstract}
The Indonesian government began using the term "new normal" in mid-May 2020, which prompted debate in the community and was reflected on social media. Therefore, the goal of this study was to use Twitter-based social media text analysis to depict the Indonesian public's impression of new normal conditions during the COVID-19 epidemic. We performed a text analysis on Twitter using the phrases "new normal" and "kenormalaan baru" with a time period of 1-31 July 2020 and location restrictions in Indonesia. The words associated with "new normal" are then described in a word cloud map and sorted in a flipped bar chart. We also performed a network bi-gram network analysis to identify word correlations in order to identify sentiments from Twitter text. When compared to other words, the word "covid" has the highest frequency. Other words linked with health protocols, such as "cuci" (wash), "tangan" (hand), "jaga" (maintain), and "jarak" (distance), appeared 1,138, 1501, 3.343, and 2.131 times, respectively, according to unigram analysis. Bigram network analysis reveals discrete clusters of phrases such as "protokol kesehatan" (health protocol), "wash hands" (cuci tangan), "jaga jarak" (physical distance), and "wear mask" (pakai masker). The word connections "covid," "pandemi" (pandemic), "lupa" (forget), "maskernya" (the mask), "lakukan" (do), "social", "distancing", "luar" (outside), "rumah" (home) also conveyed a remark about standard measures in the new normal period.
\end{abstract}

\section{Introduction}

Coronavirus disease 2019 (COVID19) is a respiratory disease caused by SARS-Cov-2. since it was first established as a pandemic by the World Health Organization (WHO) on March 11, 2020 (1), up to July 31, 2021, 198,255,899 confirmed patients have been recorded, with mortality reaching 4,229,066 in more than 200 countries (2). Some countries have shown a declining trend in the number of positive daily cases, which serve as the basis for easing restriction. In these countries activities such as trade, schools, offices and worship have gradually returned to normal, with the application of strict measurement standards, such as washing hands always using masks and maintaining physical distance. The Indonesian government began introducing the term new normal in mid-May 2020, when the President of the Republic of Indonesia on the YouTube account of the executive office announced that new normal needs to be implemented to revive the national economy, however this needs to be accompanied by strict rules in implementing standard measures to prevent transmission of the virus (3). In addition, the government socializes new normal through the New Normal video competition organized by the Ministry of Home Affairs (4). The various effort to socialize the new normal were conducted despite no sign of a decrease in the number of positive cases daily. This has sparked debate in the community, which was reflected in social media. Indonesia was the fifth country with the most Twitter users after the United States, Japan, India, Brazil, United Kingdom, Turkey and Saudi Arabia (5). With twitter users in Indonesia reaching more than 11 million. Analysis of communication on Twitter social media can be used to describe attitudes, knowledge and perceptions of health by the Indonesian public especially about the new normal condition. Recently, some reports showed the use of Twitter social media for the observation of public attention in the COVID19 pandemic era, such as new normal paradigm (6) and children's exposure to violence due to the shifting of socioeconomic condition (7).

The purpose of this study was to describe the perception of the Indonesian public, especially in the health sector of the new normal conditions during the COVID-19 pandemic, using Twitter-based social media text analysis.

\section{Methods}

\subsection{Data collection}

We collect text data from the microblogging site, Twitter. The keywords used to get texts / tweets from the Twitter public API in this study were "new normal" and "new normality" with the limitation of tweets that

\footnotetext{
* Corresponding author : dhite@ugm.ac.id
} 
speak Indonesian in the span of 30 days from July 1 to July 31, 2020. Because Twitter standards public API only allows retrieval Tweets within a period of 10 days, then data retrieval was carried out 3 times on 10, 20 and 30 July 2020.

\subsection{Data cleaning}

Data provided by the Twitter public API was in the form of data frames with features such as user identity, creation time, text content, retweet status, location and other information. In this study, we only used the tweet text feature consisting of original text and retweets.

In order for the text analysis can be well performed, it was necessary to do text processing using the principles of natural language processing as follows: change all letters to lowercase, remove punctuation, emojis, retweet notation (RT) and website links. The words "new normal" and "new normalcy" which were search keywords were also removed from the body text. In addition, words that were not standard or called "slang" need to be changed to its standard form.

Indonesian words that do not have meaning such as the conjunctions "and", "or", "but", "will" and other words called stop words were removed from the text. Finally, the clean text was separated into individual words to facilitate analysis.

\subsection{Data Analysis}

Descriptive analysis uses text data that was visualized in the form of Word Cloud, with a certain arrangement in which the words that appear most often were located in the middle of the word cloud and were the largest in size. To quantitatively assess the number of occurrences of words in the Twitter text, the frequency of the terms was presented in the form of a bar chart.

Paired words (bigram) provide more comprehensive information about the context in the analysed text, therefore bigram analysis was done by making the Network of paired words or bigram. The node represents a word by its size representing the number of words and the thickness of the connecting line represents the frequency with which word pairs occur.

All text mining, text cleaning, text analysis and visualization processes were carried out using RStudio (8).

\section{Result}

Twitter search using the keywords "new normal" and "kenormalan baru" in Indonesian language within a period of 30 days from July 1 to 31 were able to generate a total of 140,528 unique tweets consisting of original tweets and retweets. Through the process of tokenisation the Tweet text was successfully translated into $1,244,531$ words. The word "covid" has the greatest frequency compared to other words as it can be observed from the wordcloud, some terminology related to health also seems to dominate such as the word "kesehatan" (health) and mask" (Figure 1).

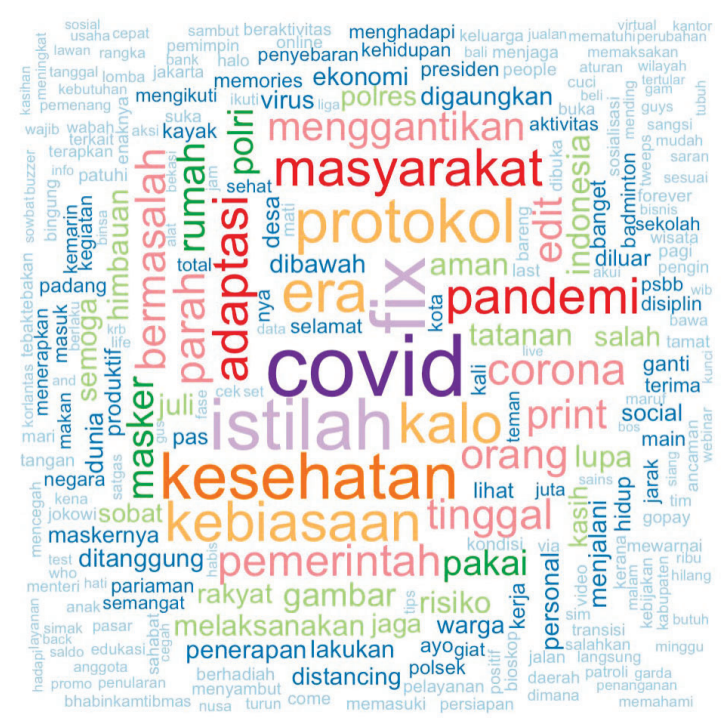

Fig. 1. Word cloud using keyword "new normal" and "kenormalan baru" (new normalcy") from 1st - 31st of July 2020.

This result was more clearly seen in the column diagram where the word "covid" ranks first with a term frequency of 15,074 words followed by other health related terminology that was included in the top 20 terms such as "kesehatan" (health), "protokol" (protocol) and "mask" with 11,392, 11,046 and 5,975 terms respectively (Figure 2). In this unigram analysis, other words associated with standard measures such as "cuci" (wash), "tangan" (hand) and "jaga" (maintain), "jarak" (distance) only appeared 1,138, 1501, 3.343 and 2.131 times, respectively.

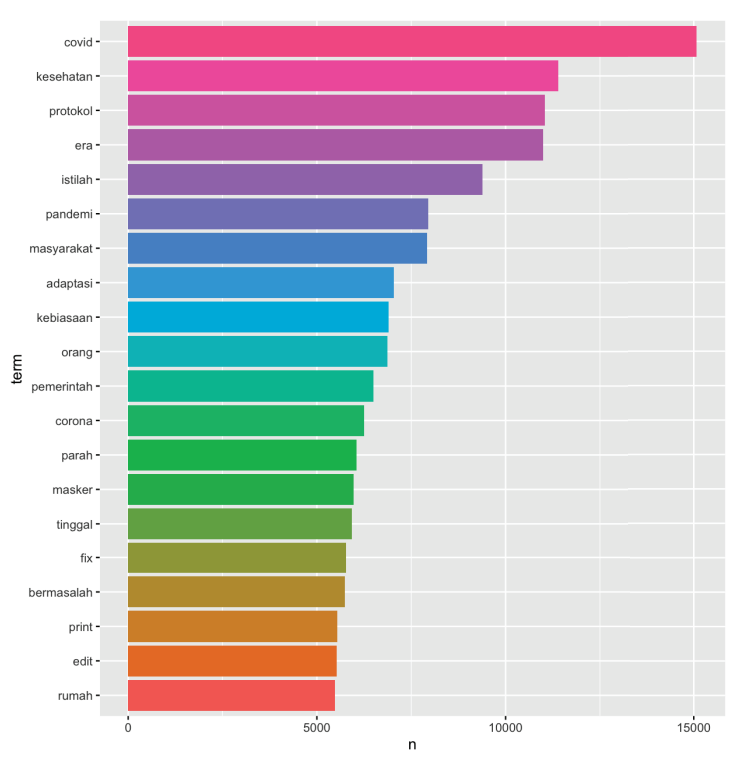

Fig. 2. Terms frequency diagram

The Bigram Count Network in Figure 3, showed distinct word pair clusters, which can be assessed from the 
distribution of nodes. Some of these clusters were isolated from each other such as "protokol kesehatan" (health protocol), "wash hands" (cuci tangan), "jaga jarak" (physical distance" and "wear mask" (pakai masker). The connections of word: "covid," "pandemi"(pandemic), "lupa" (forget), "maskernya"(the mask), "lakukan" (do), "social", "distancing", "luar" (outside), "rumah" (house) also indicated statement related to standard measures in the New Normal era. Nevertheless, a large network of interconnected words, where no terminology related to health was also observed. the large network consist of connections between "kebiasaan" (habits), "adaptasi" (adaptation), "istilah" (terminology), "menggantikan" (replace), "bermasalah" (trouble), "fix" and "parah" (severe).

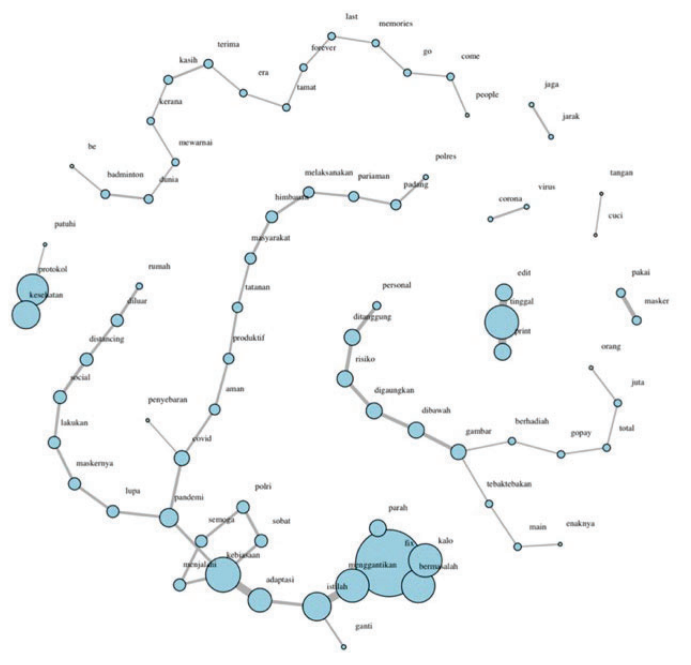

Fig. 3. The Bigram Count Network

\section{Discussion}

The word "new normal" was introduced since 1918 from Henry A. Wise Wood's writing "Beware" in the bulletin National Electric Light Association (9). In that article, the term of the new normal was used to mark the period after the First World War 1. The corona virus began to appear in December 2019 in Wuhan China, and has spread almost throughout the world. During the Covid19 pandemic, the implementation of the new normal was carried out in several countries in the world, three countries that started implementing the new normal in May 2020 includes Vietnam, New Zealand, and Germany (10).

The new normal concept was introduced through the Indonesian government website page in May 20202 (11). However, the implementation in an orderly and disciplined manner was only carried out in June 2020. Implementation in July was carried out by considering regional readiness and the results of developing epidemiological research in each related area, where the government began to loosen the public to be able to activities with terms and conditions apply. The definition of "new normal" according to the Indonesian government is a new order to adapt to covid-19. The government stated that with this new order, people were asked to remain productive by complying with all protocols to prevent the spread of the Covid-19 virus (12) .

According to Twitter analysis, the most frequently used terms juxtaposed with the phrase covid-19 are "protocol" (protocol) and "health" (health), indicating that the twitter user community believes that the adoption of a new normal paradigm is necessary in order to implement health protocols. Words related to health protocol observed on twitter analysis were "cuci" (wash), "tangan" (hand) and "jaga" (maintain), "jarak" (distance), and "masker" (mask). This finding indicates that the Indonesian people, as represented by Twitter users, have complied with the government's recommendations regarding the implementation of the new normal concept, which includes diligently washing hands with soap, maintaining a safe distance, avoiding crowds, and wearing face masks.

While some people appreciate the new normal concept, it also raises concerns, as they worried the possibility of a rise in the number of Covid-19 positive cases in Indonesia. However, some people have fully embraced the new normal concept, adapting their daily routines with health protocol in order to prevent contracting the virus (13). Indonesians responded positively to the policy's implementation. The community's use of masks was favorable in some regions; for example, 95.8 percent of residents in Wonosobo region used face masks every time they left the house (14), and another survey of undergraduate students in Indonesia revealed that 86.8 percent followed health protocols (15). Indonesians have good social distancing behavior as well, indicated by 93 percent of respondents applying social distancing(16) .

Without public trust, it is exceedingly difficult to persuade people to engage in disease prevention behaviors. Individuals' views of the danger of illness will influence their behaviour or activities in order to comply to one or more prescribed habits (17), (18). The outcomes of this study suggested that the majority of Indonesians adhered to the Ministry of Health's and World Health Organization's health protocols. As indicated in Figure 1, the majority of Indonesians understand the phrases "kesehatan" (health) and "masker" (mask). Additionally, we can extrapolate from Indonesia's perspective that the new normal concept is seen favourably. Adopting the "new normal" approach will necessitate collaboration between the community and the government in order to avoid adverse impacts and shorten the duration of the Covid-19 pandemic in Indonesia.

\section{Conclusion}

The Indonesian government is actively promoting the term "new normal" in mid-May 2020 in order to keep people productive in the midst of the COVID-19 coronavirus pandemic by proceeding to practice clean and healthy living principles and implementing health protocols such as regularly washing hands with soap, wearing masks when leaving the house, keeping a safe 
distance, and avoiding crowds. This strategy is implemented not only in the economic field, but also in education and religion, in order to control the covid-19 transmissions.

The results of the text analysis on Twitter reveal that the Indonesian people understand the concept of "new normal" in accordance with the expectations of the Indonesian government, as seen by the conversation on Twitter about "new normal" which has been associated with the terminology of health protocols. This text analysis on Twitter can be used to describe the Indonesian people's opinion on the concept of "new normal." Nonetheless, further research employing a direct survey method in the public is required to analyze the community's knowledge, attitudes, and practices.

\section{References}

1. who-audio-emergencies-coronavirus-pressconference-full-and-final-11mar2020.pdf [Internet]. [cited $2021 \mathrm{Jul}$ 31]. Available from: https://www.who.int/docs/defaultsource/coronaviruse/transcripts/who-audioemergencies-coronavirus-press-conference-fulland-final-11 mar2020.pdf?sfvrsn=cb432bb3 2

2. COVID Live Update: $198,255,899$ Cases and 4,229,066 Deaths from the Coronavirus -

Worldometer [Internet]. [cited $2021 \mathrm{Jul} 31$ ]. Available from:

https://www.worldometers.info/coronavirus/

3. TV CI. Terdampak Covid-19, RI Siap Masuki Era New Normal? [Internet]. CNBC Indonesia. [cited $2021 \mathrm{Jul}$ 31]. Available from:

https://www.cnbcindonesia.com/news/202005201 12734-8-159783/terdampak-covid-19-ri-siapmasuki-era-new-normal

4. Mendagri Jelaskan soal Lomba Video New Normal Rp 168 M: Bukan Hamburkan Uang [Internet]. [cited $2021 \mathrm{Jul} 31$ ]. Available from: https://news.detik.com/berita/d-

5066152/mendagri-jelaskan-soal-lomba-videonew-normal-rp-168-m-bukan-hamburkan-uang

5. Indonesia Fifth-Largest Country in Terms of Twitter Users [Internet]. [cited 2021 Jul 31]. Available from:

https://jakartaglobe.id/news/indonesia-fifthlargest-country-in-terms-of-twitter-users/

6. Rahmanti AR, Ningrum DNA, Lazuardi L, Yang $\mathrm{HC}$, Li YCJ. Social media data analytics for outbreak risk communication: public attention on the "New Normal" during the COVID-19 pandemic in Indonesia. Comput Methods Programs Biomed. 2021 Jun;205:106083.

7. Babvey P, Capela F, Cappa C, Lipizzi C, Petrowski N, Ramirez-Marquez J. Using social media data for assessing children's exposure to violence during the COVID-19 pandemic. Child Abuse Negl. 2021 Jun;116:104747.

8. R: The R Project for Statistical Computing [Internet]. [cited 2021 Jul 31]. Available from: https://www.r-project.org/

9. There's nothing new about the "new normal" and here's why [Internet]. World Economic Forum. [cited $2021 \mathrm{Jul}$ 31]. Available from: https://www.weforum.org/agenda/2020/06/theresnothing-new-about-this-new-normal-heres-why/

10. Germany, Vietnam, and New Zealand reopening schools despite coronavirus - Vox [Internet]. [cited $2021 \mathrm{Jul}$ 31]. Available from: https://www.vox.com/21270817/coronavirusschools-reopen-germany-vietnam-new-zealand

11. Sparrow R, Dartanto T, Hartwig R. Indonesia Under the New Normal: Challenges and the Way Ahead. Bulletin of Indonesian Economic Studies. 2020 Sep 1;56(3):269-99.

12. Indonesia.go.id - Mengenal Konsep New Normal [Internet]. [cited 2021 Jul 31]. Available from: https://indonesia.go.id/ragam/komoditas/ekonomi/ mengenal-konsep-new-normal

13. Teasdale E, Santer M, Geraghty AWA, Little P, Yardley L. Public perceptions of nonpharmaceutical interventions for reducing transmission of respiratory infection: systematic review and synthesis of qualitative studies. BMC Public Health. 2014 Jun 11;14(1):589.

14. Purnamasari I, Raharyani AE. TINGKAT PENGETAHUAN DAN PERILAKU MASYARAKAT KABUPATEN WONOSOBO TENTANG COVID -19. Jurnal Ilmiah Kesehatan. 2020 May 31;10(1):33-42.

15. Saefi M, Fauzi A, Kristiana E, Adi WC, Muchson M, Setiawan ME, et al. Survey data of COVID19-related knowledge, attitude, and practices among indonesian undergraduate students. Data Brief. 2020 Aug;31:105855.

16. Yanti B, Mulyadi E, Wahiduddin W, Novika RGH, Arina YMD, Martani NS, et al. Community knowledge, attitudes, and behavior towards social distancing policy as prevention transmission of covid-19 in indonesia. Jurnal Administrasi Kesehatan Indonesia. 2020 Jun 17;8(0):4-14.

17. Tang CS, Wong C. Factors influencing the wearing of facemasks to prevent the severe acute respiratory syndrome among adult Chinese in Hong Kong. Prev Med. 2004 Dec;39(6):1187-93.

18. Lau JTF, Yang X, Tsui H, Kim JH. Monitoring community responses to the SARS epidemic in 
Hong Kong: from day 10 to day 62. J Epidemiol Community Health. 2003 Nov;57(11):864-70. 